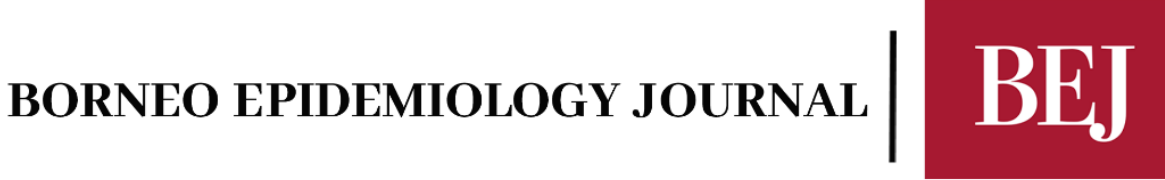

\section{Mitigation Measures during Elections and It's Impacts on COVID-19 Pandemic: Sabah State (Malaysia), New Zealand and the United States}

\author{
Syaza Zainudin, ${ }^{1}$ Mohd Amiruddin Mohd Kassim, ${ }^{1, *}$ Nor Nadia Mohamad Ridza ${ }^{2}$
}

\section{Abstract}

Background and Objective: Countries all over the world respect the election process as one of the fundamental steps in forming a government. However, the exponential spread of COVID-19 has been deeply alarming, with a high number of positive cases and total deaths, forcing World Health Organization to declare it as a pandemic on $11^{\text {th }}$ March 2020. During these unprecedented events, governments have had a tough decision to balance between the constitutional obligation to hold an election and the safety of the people. As such, electoral commissions have implemented numerous approaches to allow election to proceed in a safe and controlled setting during the pandemic.

Methods: The preventative measures and standard operating procedures in the Sabah state of Malaysia, New Zealand and the United States elections are discussed, as well as COVID19 post-election situation in respective countries. Innovative approaches and election flexibilities shall be considered to allow voting in the safest way possible, following the new normal.

Discussion: Nevertheless, countries need to evaluate its strength of public health response when deciding to hold elections due to potential devastating outbreaks following elections despite measures taken.

Conclusion: The election is a fundamental process in a democracy. Countries are required to be flexible and innovative in their approach to hold a safe election. Nevertheless, it may be prudent for countries with fewer resources and poor pandemic control to postpone election as a rise in cases will be catastrophic, putting many lives at risk.

Keywords: Election, COVID-19, voting, Sabah, New Zealand, United States

Correspondence Email: amiruddink@ums.edu.my

${ }^{1}$ Faculty of Medicine and Health Sciences, Universiti Malaysia Sabah, Kota Kinabalu, 88400, Sabah, Malaysia

${ }^{2}$ Emergency and Trauma Department, Sabah Women and Children Hospital, Ministry of Health Malaysia, Kota Kinabalu, 88400 Sabah, Malaysia

Received: $28 / 11 / 2020$

Accepted: 13/12/2020 


\section{Introduction}

Severe acute respiratory syndrome coronavirus 2 (SARS-COV-2) is the virus strain that causes COVID-19 pandemic that has grappled the world since March 2020. It is transmitted via respiratory droplets, highly infectious in closed spaces and prolonged exposures (Cevik, M. et al., 2020). Many countries have had some form of government instituted "Lockdown" as a part of public health measures to curb the spread, much to the detriment of the economy and social mobility. Malaysia went through its Movement Control Order (MCO), heavily regulated with multi enforcement agency involvement and has seen success at flattening the second wave that started in late February of 2020 with only 277 cases recorded. (MHM; 04 June, 2020).

Malaysia operates a few level of lockdown, Enhanced MCO (EMCO) is a more stringent order for specific locations where a high number of cases from clusters were found, Conditional MCO (CMCO) have more relaxed regulations that aim to reopen the economy safely. The Recovery MCO (RMCO) allows for interstate travel and lifting of most restrictions, it was introduced on the $10^{\text {th }}$ of June after successful 'flattening of the curve' (reduction of projected number of cases with public health intervention). Although the borders were closed, Malaysians were free to travel within the country with constant iterations to adopt the new normal of physical distancing and compulsory mask-wearing in public places (MHM; 01 August, 2020). However, the country's pandemic response was tested when the third most populous state (3.2million) situated in its Bornean Island, Sabah went through a state election. Other countries such as the United States, New Zealand, South Korea, and Singapore have also held their general elections, while 67 countries have seen its election postponed (IFES; 17 November, 2020).

Hence, International Foundation for Electoral Systems (IFES), an international and non-profit organization that provides technical support and engages in critical issues in regards of democracy and election, has published useful guidelines and recommendations on conducting election during the pandemic (IFES; 21 October, 2020). IFES has engaged and actively observing elections in many countries such as Libya, Tajikistan, Czech Republic, Moldova and Myanmar. IFES recommendations have been an important reference to electoral commissions all over the world in effort to build sustainable democracy.

This article will discuss the situation and protective measures taken during the election period, as well as COVID-19 trend post-election in Sabah (Malaysia), New Zealand and the United States between September and November 2020.

\section{Methods}

\section{Sabah, Malaysia}

The state election was held on the $26^{\text {th }}$ of September after the dissolution of the State Legislative Assembly on the $30^{\text {th }}$ of July 2020. A standard operating procedure (SOP) was released by the Election Commissions of Malaysia which covered campaigning as well as voting guidelines. Campaigning involved public rallies, home visits, and inter-state travel between east and west Malaysia (MEC; 20 September, 2020). 
Public gatherings were limited to 250 people, subject to venue capacity with physical distancing of 1 meter. Home visits were allowed limited to 3 persons, with no physical contact. The electoral commission opened postal votes for election workers, absent voters abroad, and authorized health and security personnel. Other than the aforementioned groups, no postal voting was allowed (MEC; 22 September, 2020). This includes Sabahans residing in Sarawak or peninsula Malaysia, which was estimated at 250,000 people, including the elderly, who were more susceptible to complications of COVID-19 infection (Boo, S., 24 August 2020). Early voting was allowed for policemen and military personnel on the $22^{\text {nd }}$ of September for 16,877 eligible voters (MEC; 22 September, 2020). COVID-19 patients were not allowed to vote, and individuals under quarantine order were allowed to vote after health clearance with the district health officer (ECM; 27 September 2020).

On polling day, voters were required to adhere to time slots as stated in their voter's cards to avoid congestion. Temperatures were taken; voters with symptoms were taken aside to vote in a separate area and received immediate medical attention from healthcare workers (MEC; 20 September, 2020). The electoral commission reported 749,083 voters or a $66.61 \%$ voter turnout, including postal and early voters (ECM; 27 September 2020).

Sabah saw a rise in cases before polling day with the first case identified at a detention centre in Lahad Datu on the $1^{\text {st }}$ September 2020. Transmission from residents to workers at the centre caused a community outbreak. This cluster is the largest in Sabah with a total of 1146 cases (MHM; 28 August, 2020). Cases in Tawau, and Lahad Datu started increasing prior to voting day, whilst other regions saw an increasing trend after the Election Day. Interior division of Sabah which rarely records cases was also affected. The porous borders also attributed to the cases on the East Coast (Figure 1).

Enhanced MCO was enforced in Tawau prison from $11^{\text {th }}$ of September, and Tawau division was subsequently under Conditional MCO on the $29^{\text {th }}$ of September after polling day. The West Coast followed with reinstatement of CMCO on the $7^{\text {th }}$ of October 2020, and eventually a state-wide directive for CMCO was implemented on $12^{\text {th }}$ of October 2020 due to a rise in community spread. Schools were closed, inter-district travels were restricted, and only essential services were allowed to operate (Ibrahim, M.I., 11 October, 2020).

During the campaign and voting period, inter-state travel was permitted which have caused some spread to the Peninsular Malaysia. As of $21^{\text {st }}$ of November 2020, 31 new clusters were identified across 9 states in West Malaysia linked to Sabah returnees contributing to a total of 528 cases (Figure $2 \boldsymbol{\&} \mathbf{3}$ ). Before the rise of cases, a mandatory quarantine of 14 days was not imposed on returnees, however, quarantine and testing were then made mandatory with the increasing trend of cases linked to Sabah. Selangor and the Federal State of Kuala Lumpur and Putrajaya had the most cases with 15 clusters seen (Abdullah. N.H., 20 November 2020). 
Although the election was constitutionally mandatory and held under a seemingly safe and controlled setting, it ultimately led Malaysia into the third wave of the pandemic. Due to the logistical and resource issues in Sabah, in addition to movement control order and test, trace and isolate strategy, the Ministry of Health Malaysia had to mobilise the workforce from the Peninsular Malaysia. This has successfully reduced the $\mathrm{R}_{0}$ from 2.2 to 1.06 in 6 weeks (Abdullah. N.H., 01 November, 2020). However, the economic and social burden of this strategy is immense.

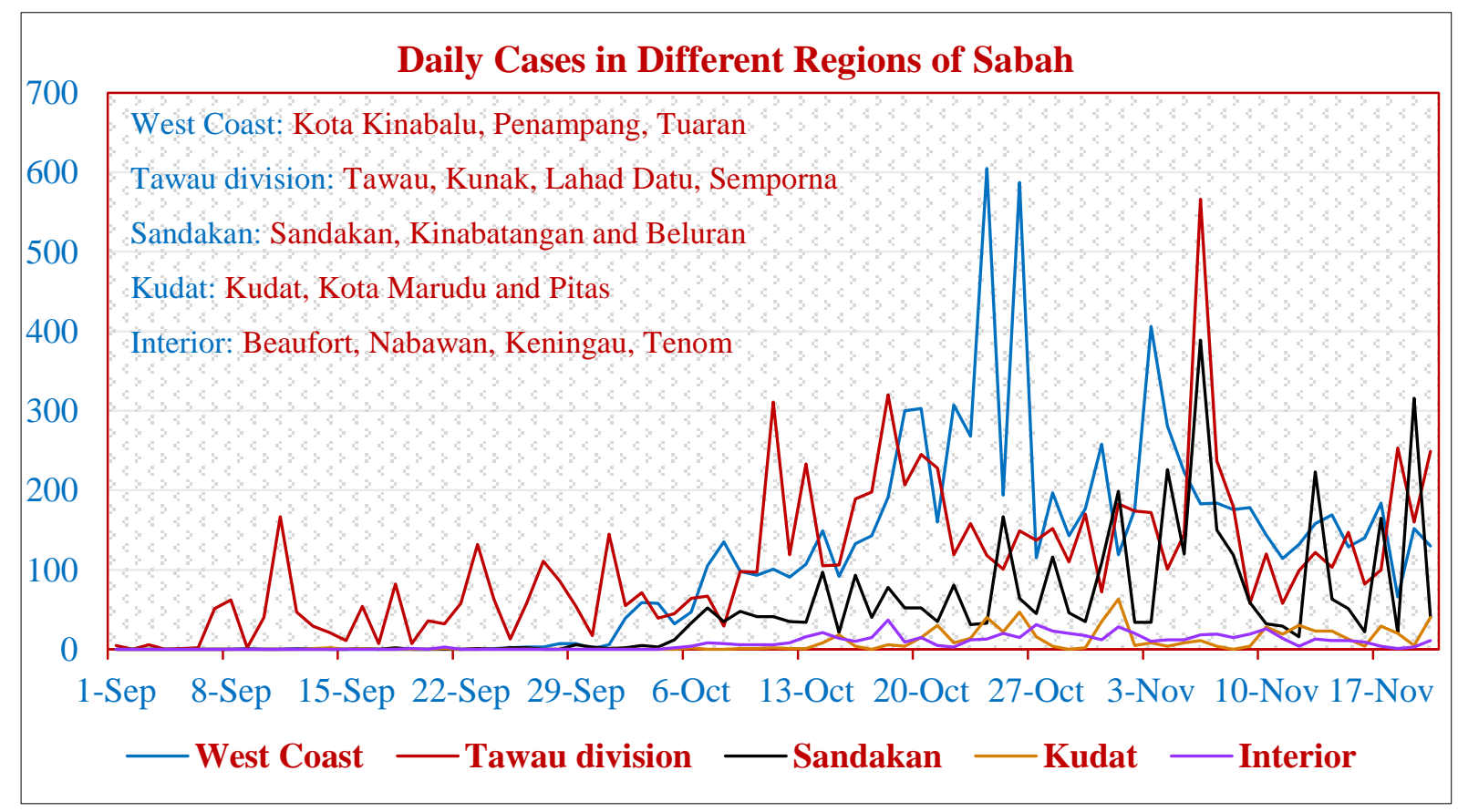

Figure 1: Trend of weekly COVID-19 cases according to divisions

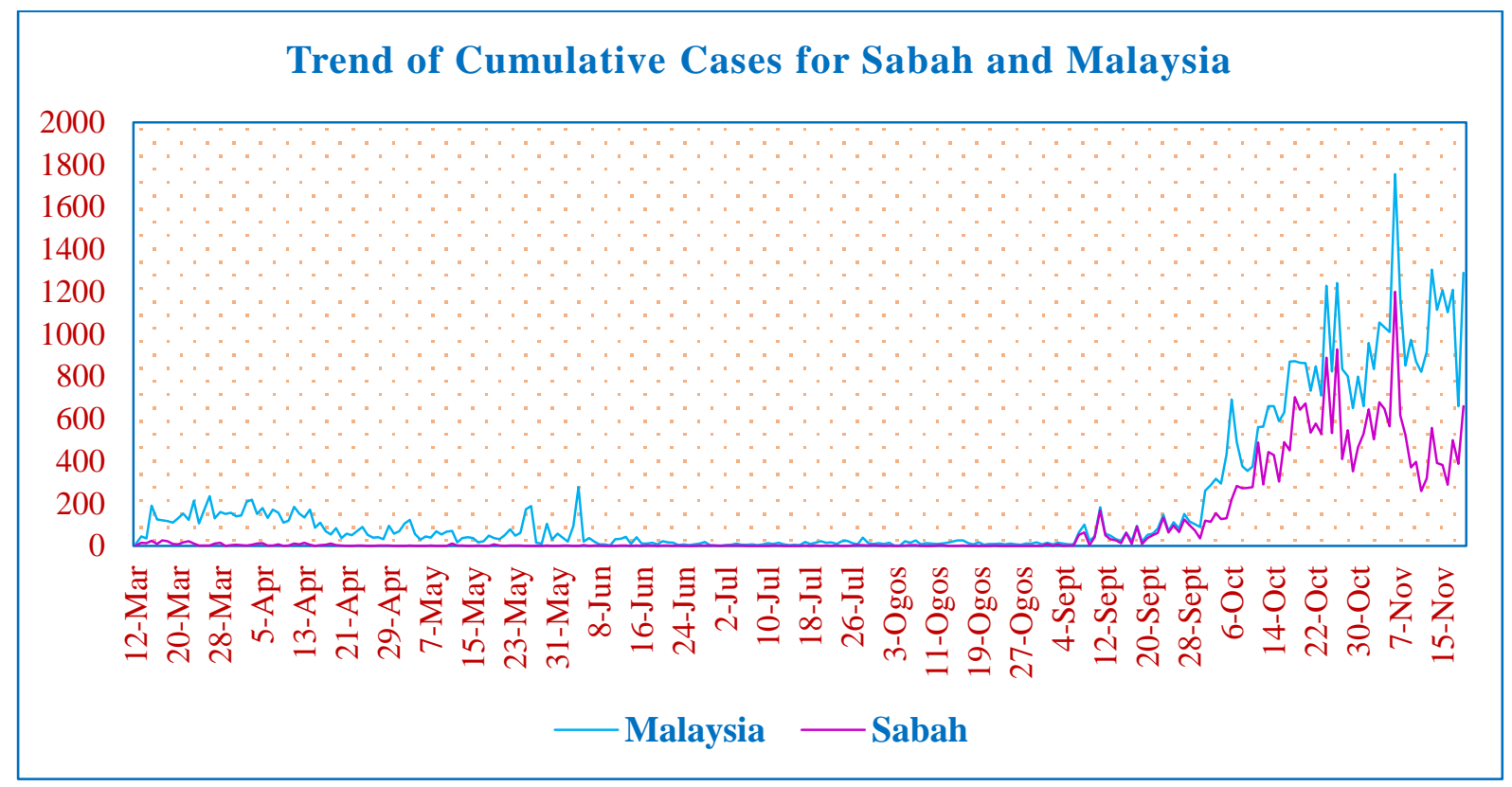

Figure 2: COVID-19 Case Trends in Malaysia and Sabah 


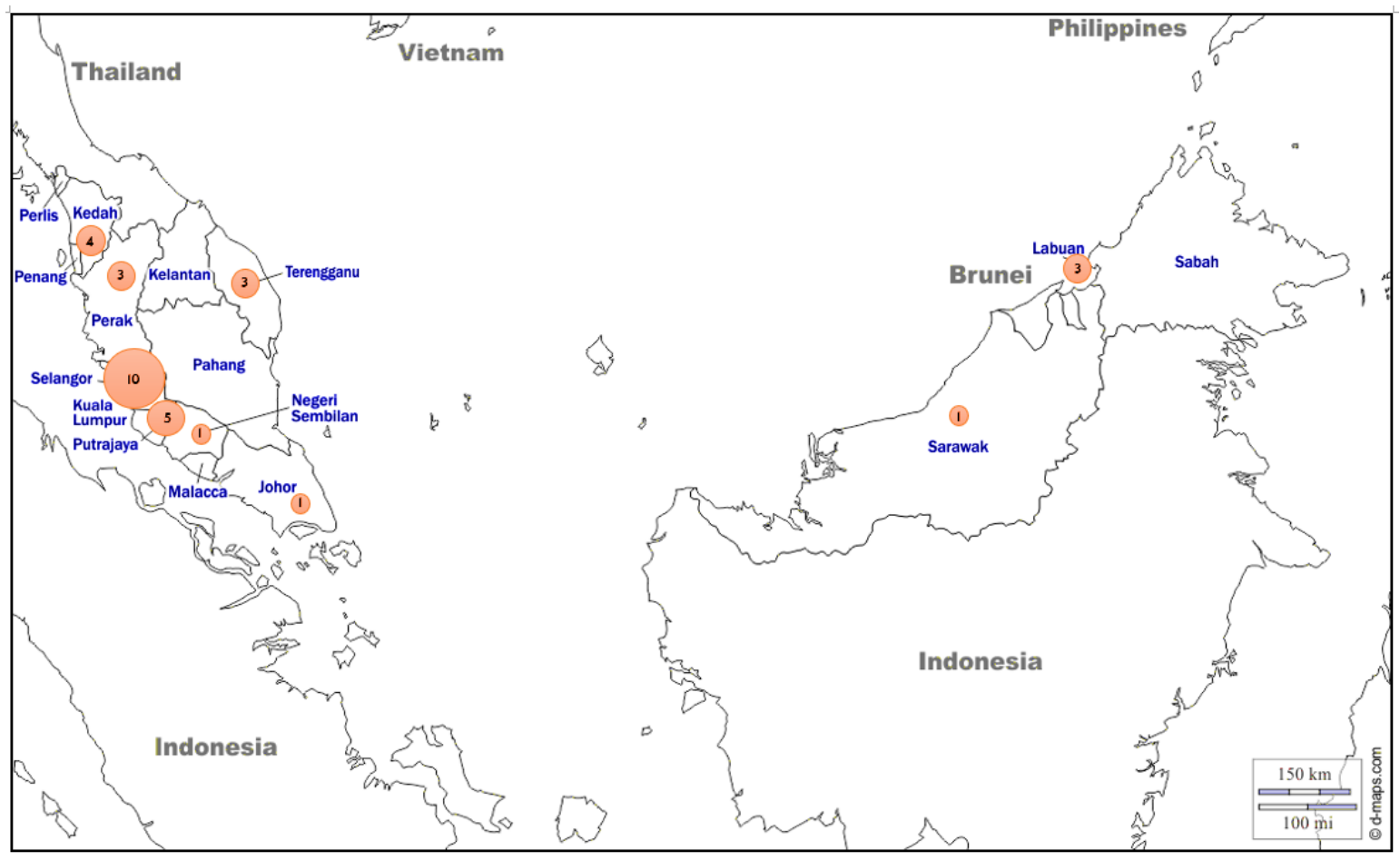

Figure 3: Number of clusters linked to Sabah returnees across Malaysia

\section{New Zealand}

An islandic country in Oceania region with an estimated population of 5,101,400 as of 20th September 2020 (Stats, 30 September, 2020), New Zealand has been among the better countries in dealing with COVID-19. It was contributed by the swift and decisive action taken by the government, implemented a stringent nationwide lockdown on 26th March 2020 which lasted for 7 weeks, as well as strong border control, which was easier for remote island states, as compared to other countries (Baker, M.G et. al., 2020; Cousins, S. 2020). Subsequently, the number of positive cases drastically reduced and New Zealand was among the earliest to flatten the curve.

As a democratic country, New Zealand held its election every three years, which recently took place on 17 th October 2020. Prior to the election, New Zealand had 46 active cases, all of which were imported cases, with a total cumulative number of 1,524 as of 16th October 2020 (MHNZ; 16 October, 2020). In fact, New Zealand was on 3-weeks streaks of no community COVID-19 case, which was last detected on 25th September 2020 (MHNZ; 25 September, 2020). With these reassuring figures, the New Zealanders went on to vote as planned on 17th October 2020.

The Electoral Commission of New Zealand introduced several measures to accommodate the voting process during this pandemic. One of the measures was to allow advance voting starting from two weeks before the election date, to reduce queues and crowds in the voting centers (Ensor, J., 13 October, 2020). These voting centers also adopted preventive measures by increasing the size and number of voting places, promoting contact tracing phone application, abundant hand sanitizers, encouraging voters to bring their pen, as well as observing social distancing rules (ECNZ; 03 October, 2020). 
Apart from that, the category of voters allowed for postal vote also widened, allowing citizens in rest homes, prisons, overseas, and hospitals to cast their vote. Even registered voters in isolation or quarantine facilities also can exercise their rights to vote by telephone dictation service, to minimize the risk of COVID-19 transmission (ECNZ; 03 October, 2020).

With these proactive initiatives, New Zealand was able to conduct the election in a controlled setting. Despite recording of one positive COVID-19 community case on the next day i.e., on $18^{\text {th }}$ October 2020 (Roy. E.A., 18 October, 2020), the pandemic still appeared under control, with the cases for the next two weeks post-election varied from zero to 25 cases daily, and the majority of the positive cases were imported cases constituting around $95 \%$ of the daily cases. As of 18th November 2020, approximately one month after the election, the cumulative confirmed cases were 1652 cases (MHNZ., 18 November, 2020), an increase of 128 cases compared to pre-election, with the community cases approximately 15 to 20 percent of the increase. Meanwhile, the total deaths were 25 cases, and thus, death rate of 0.015 percent, significantly lower than most countries (Figure 4). New Zealand has proven that an election certainly could be held during the pandemic, with the help of strict preventive measures and a relaxed voting process, while ensuring the integrity and voices of its citizens will always remain respected.

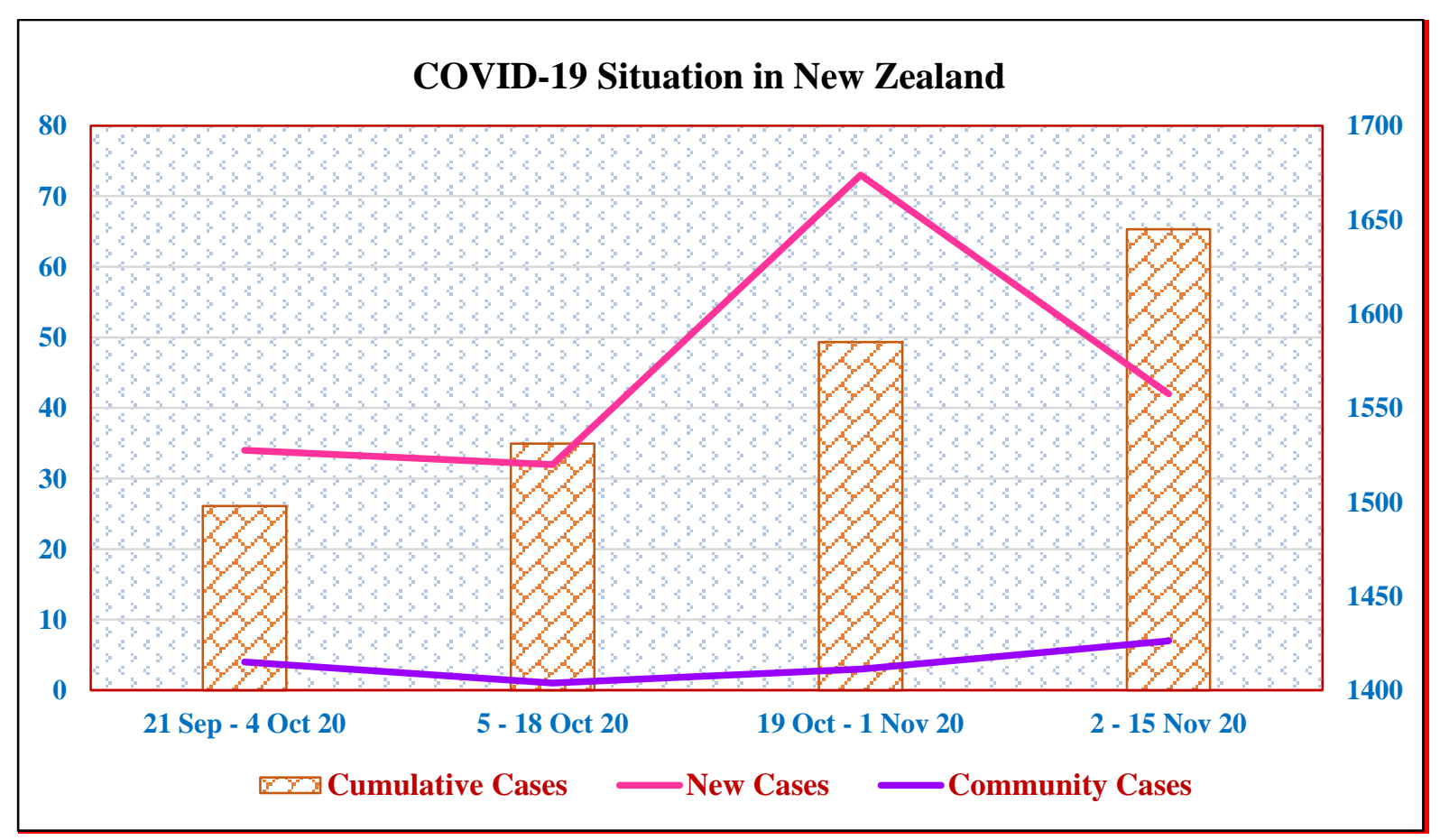

Figure 4: COVID-19 Situation One Month Prior and After Election on $17^{\text {th }}$ October 2020

\section{United States}

The United States of America, or commonly known as United States (US), is a country in the North American continent, between Canada and Mexico. The US consists of 50 states and an estimated population of 328,239,523 as of 1st July 2019, making it the third-most populous country in the world (USCB, 19 November, 2020). 
As COVID-19 swept across countries all over the world, US was not spared, having recorded its first case on 20th January 2020 (Holshue, M.L. et. al., 2020). Since then, positive cases and death rates have exponentially increased, surpassing China, India, and Italy, becoming the leading country in terms of the highest number of COVID-19 positive cases and highest total deaths (Miller, I.F. et. al., 2020). Despite its technological advancement, the healthcare professionals were alarmed by the possibility of an overburdened and overwhelmed healthcare system if the infection trend does not show any signs of improvement soon (Perc, M., et. al., 2020).

The worry turned into a major concern with the looming general election in early November. The US held its election every 4 years, and the highly anticipated US election between President Trump (Republican) and Joe Biden (Democrats) on 3rd November 2020, was bound to cause increased movement intra- and interstate as well as mass gathering, hence increasing the risk of COVID-19 transmission (James, T.S., et. al., 2020). In view of this, Centres for Disease Control and Prevention (CDC) and US Election Assistance Commission (EAC) have proposed numerous recommendations to minimize the risk during the election period. Among the recommendations were observing social distancing, frequent cleaning and disinfection of the polling place, handwashing, as well as offering masks and gloves (USEAC; 19 November, 2020). Physical barriers like plexiglass shields were also used between workers and voters and between voting stations. Postal votes also showed a significant increase, with more than 65 million postal votes sent in (BBCN; 06 November, 2020).

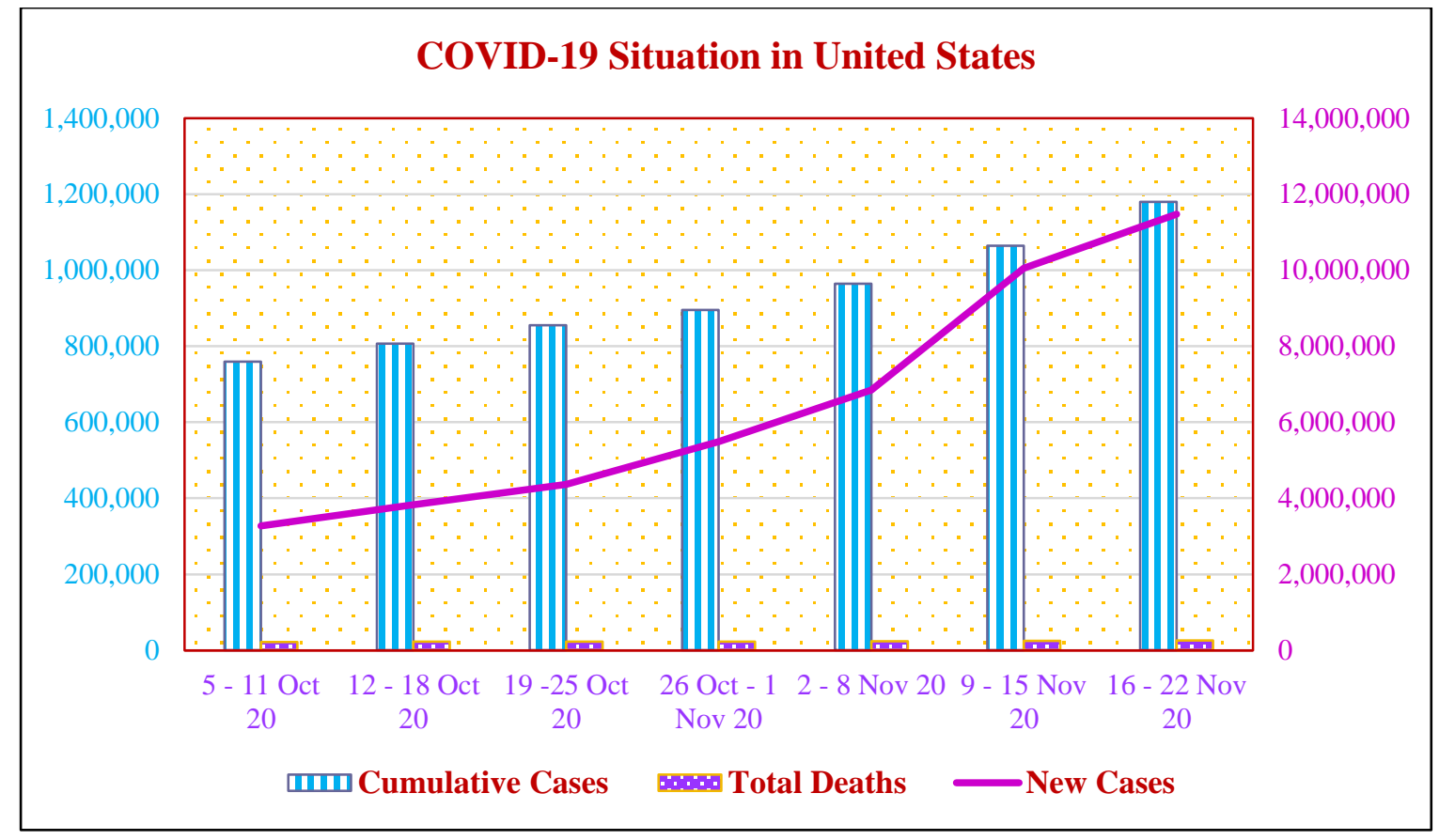

Figure 5: COVID-19 Situation Prior and After Election $3^{\text {rd }}$ Nov 2020

Despite the encouraging actions, wearing a face mask was not made mandatory nationwide, as this falls under the jurisdiction of state governors. States such as Oklahoma, Nebraska, Missouri, and Mississippi encouraged the use of face mask but rejected the calls for state mandate (Markowitz, A., 17 November 2020). 
Hence, voters were able to go to polling stations without wearing a face mask, which increased the risk of COVID-19 transmission (Waldmeir, P.; 29 October 2020). To make things worse, large-scale political rallies were held at various venues all over the countries (AJ; 31 October 2020), with little practice of wearing masks and physical distancing.

A month before the election, there were $7,645,156$ positive cases and 214,690 total deaths in the US. As of $18^{\text {th }}$ November 2020 (approximately two weeks post-election), there were 11,300,635 cumulative COVID-19 positive cases and 247,834 total deaths recorded in the US (CDC; 18 November, 2020). A significant increase of 3,655,479 positive cases was seen in just 6 weeks, and total deaths also increase by 33,144, which equates to a death rate of $0.022 \%$ (Figure 5). The most worrying thing is this data is only illustrating the COVID-19 situation two weeks post-election and based on the earlier Sabah state election in Malaysia scenario, the US may show a similar increasing infection trend. The updated forecasts based on these alarming surge of cases offered grim outlook, and with Thanksgiving and Christmas on the horizon, the worst is perhaps yet to come (CDC; 11 December, 2020).

\section{Discussion}

There is no doubt that election is an integral part of democracy. As such, to uphold the constitution status as the supreme law of the country, countries must abide by and hold elections accordingly. There are only a few exceptions that can result in the postponement of an election such as a state of emergency, but never to cancel the election altogether (James, T.S. et. al., 2020). Article 21(3) of the Universal Declaration of Human Rights notes that states must have regular, periodic elections (35). Article 4 of the International Covenant on Civil and Political Rights, meanwhile, states that "in time of public emergency which threatens the life of the nation and the existence of which is officially proclaimed, the States Parties may take measures derogating from their obligations under the present Covenant to the extent strictly required by the exigencies of the situation" (UNGA; 1966).

In Malaysia, Yang di-Pertuan Agong is the constitutional monarch and the head of state of Malaysia. His Majesty was elected by the Conference of Rulers, which comprised of the nine rulers of the Malay states. His Majesty has the absolute power to prorogue or dissolve the parliament and call for an election, as well as the power to declare a state of emergency. Likewise, in New Zealand and the US, the power to dissolve the parliament or postpone the election is in the hands of the Governor-General and US Congress, respectively. The commitment to call for election is certainly not a decision made lightly and done after careful deliberation and extensive due diligence.

As shown by New Zealand, a truly democratic process can be continued amid pandemic, with the proviso that the necessary precautionary measures are complied with and adopted, as well as encouraging innovative approach to enable citizens to fulfil their responsibilities and choosing the government (Gunia, A., 12 October, 2020). On the other hand, Malaysia, for its part, had initial relative success in flattening the curve. 
The decisive actions by the government to implement Movement Control Order (MCO) back in March 2020 were instrumental in Malaysia's effort to reduce the $\mathrm{R}_{0}$ to less than one. In the run up to Election Day in Sabah and the US, large-scale political gatherings and campaigns held by the political parties resulted in a surge of new cases, ultimately leading Malaysia into the third wave of the pandemic (TST; 18 November 2020). Although the Electoral Commission of Malaysia has enforced a strict standard operating procedure (SOP) for the election to control the risk of COVID-19, it certainly had room for further improvement.

In these unprecedented times, embracing the new normal is a matter of survival. With vaccine development still in progress, this pandemic is far from ending (Jabbari, P., 2020). Many sectors, such as education and business have evolved and transitioned to the virtual environment, following the new normal. Admittedly, a similar shift in operational methods is difficult to achieve in an election. It is a monumental process in which the possibility of error or manipulation cannot be tolerated, but the pandemic has challenged the traditional approach and calls for the election process to be reviewed. Perhaps, election flexibility as shown by New Zealand could be the perfect example of how to conduct a safe election.

\section{Conclusion}

The election is a fundamental process in a democracy. Countries are required to be flexible and innovative in their approach to hold a safe election. Nevertheless, it may be prudent for countries with fewer resources and poor pandemic control to postpone election as a rise in cases will be catastrophic, putting many lives at risk.

\section{Conflict of Interest}

The authors wish to declare that there is no conflict of interest. No funding was received.

\section{Authors Contribution}

All authors contributed equally to this work.

\section{Acknowledgements}

The authors would like to thank COVID-19 Preparedness and Action Centre University Malaysia Sabah for data on COVID-19 trends in Sabah and Malaysia.

\section{References}

Abdullah. N.H., Current Situation of Coronavirus Disease 2019 (COVID-19) in Malaysia. KPK Press Statement, 20 November 2020. https://kpkesihatan.com/author/pejabatkpk/

Abdullah. N.H., Decreased R Value in Malaysia. COVID-19 Malaysia, 01 November, 2020. http://covid-19.moh.gov.my/sorotan/112020/penurunan-nilai-r-di-malaysia

AJ (Al Jazeera), Trump Rallies Linked to Thousands of COVID-19 Cases, Study Finds. Al Jazeera News, 31 October 2020. https://www.aljazeera.com/news/2020/10/31/trump-rallies-linked-tothousands-of-covid-19-cases-study-finds 
Baker, M.G., Kvalsvig, A., Verrall, A.J., Barnard, L.T., Wilson, N. (2020). New Zealand's Elimination Strategy for the COVID-19 Pandemic and What is Required to Make it Work, N. Z. Med. J., 133(1512), 10-14. https://www.nzma.org.nz/journal-articles/new-zealands-eliminationstrategy-for-the-covid-19-pandemic-and-what-is-required-to-make-it-work

BBCN (BBC News), US Election 2020: Do Postal Ballots Lead to Voting Fraud? 06 November, 2020. https://www.bbc.com/news/world-us-canada-53353404

Boo, S. Don't Turn Sabah Red By Barring Postal Voting, CodeBlue, 24 August 2020. https://codeblue.galencentre.org/2020/08/24/dont-turn-sabah-red-by-barring-postal-voting/

CDC (Centres for Disease Control and Prevention), United States COVID-19 Cases and Deaths by State, CDC COVID Data Tracker, 18 November, 2020. https://covid.cdc.gov/covid-datatracker/\#cases_casesper100klast7days

CDC (Centres for Disease Control and Prevention). COVID-19 Forecasts: Cases, 11 December 2020. https://www.cdc.gov/coronavirus/2019-ncov/cases-updates/forecasts-cases.html

Cevik, M., Kuppalli, K., Kindrachuk, J., Peiris, M. (2020). Virology, Transmission, and Pathogenesis of SARS-CoV-2. BMJ, 371, m3862(1-6). https://www.bmj.com/content/bmj/371/bmj.m3862.full.pdf

Cousins, S. (2020). New Zealand Eliminates COVID-19. Lancet, 395(10235):1474. https://www.thelancet.com/action/showPdf?pii=S0140-6736\%2820\%2931097-7

ECM (Election Comission of Malaysia). 16,877 Orang Mengundi Awal Bagi Pilihan Raya Umum Dewan Undangan Negeri (PRU DUN) Sabah Ke-16 Pada, 22 September 2020. https://www.spr.gov.my/sites/default/files/KM\%20BIL\%2060_KM\%20PENGUNDI\%20AWA L\%20MENGUNDI.pdf

ECM (Election Commission of Malaysia). Keputusan Penuh Pengundianpilihan Raya Umum Dewan Undangannegeri Sabah Ke-16, 27 September 2020.

https://www.spr.gov.my/sites/default/files/KM\%20BIL\%2064\%202020\%20KENYATAAN\%2 0MEDIA\%20KEPUTUSAN\%20PENUH\%20PENGUNDIAN\%20PRU\%20DUN\%20SABAH \%20KE\%2016.pdf

ECNZ (Electoral Commission of New Zealand), COVID-19, 03 October, 2020. https://vote.nz/voting/2020-general-election/covid-19/

Ensor, J., NZ Election 2020: Advance Voting Expected to Blast Past Electoral Commission Target. Newshub, 13 October, 2020. https://www.newshub.co.nz/home/politics/2020/10/nz-election2020-advance-voting-expected-to-blast-past-electoral-commission-target.html

Gunia, A., New Zealand's Election Offers a Glimpse of a Calmer Democracy in the Time of COVID19, Time, 12 October, 2020. https://time.com/5897240/new-Zealand-elections-ardern/

Holshue, M.L., DeBolt, C., Lindquist, S., Lofy, K.H., Wiesman, J., Bruce, H., Spitters, C., Ericson, K., Wilkerson, S., Tural, A., Diaz, G., Cohn, A., Fox, L., Patel, A., Gerber, S.I., Kim, L., Tong, S., Lu, X., Lindstrom, S., Pallansch, M.A., Weldon, W.C., Biggs, H.M., Uyeki, T.M., Pillai, S.K. (2020). First Case of 2019 Novel Coronavirus in the United States. N. Engl. J. Med., 382(10), 929-936. https://www.nejm.org/doi/full/10.1056/NEJMoa2001191

Ibrahim, M.I., SOP Perintah Kawalan Pergerakan Bersyarat (Pkpb) Di Daerah Kota Kinabalu, Penampang Dan Putatan, Sabah. Malaysian National Security Council, 11 October, 2020. http://covid-19.moh.gov.my/faqsop/sop-pkp-pemulihan/04_SOP-PKPB-KK-SABAH_Dikemaskini-pada-11-Oktober-2020.pdf

IFES (International Foundation for Electoral Systems). Elections Postponed Due to COVID-19 - As of November 17, 2020. https://www.ifes.org/sites/default/files/elections_postponed_due_to_covid-19.pdf 
IFES (International Foundation for Electoral Systems). Featured Elections Held and Mitigating Measures Taken During COVID-19 - As of October 21, 2020.

https://www.ifes.org/sites/default/files/elections_held_and_mitigating_measures_taken_during_ covid-19.pdf

Jabbari, P., Rezaei, N. With Risk of Reinfection, Is COVID-19 Here to Stay? (2020). Disaster Med.

Public Health Prep., 14(4), e33. https://www.cambridge.org/core/journals/disaster-medicineand-public-health-preparedness/article/with-risk-of-reinfection-is-covid19-here-tostay/C4A2A602F96D6E1B3352BF91A6E427E5

James, T.S., Alihodzic, S. (2020). When Is It Democratic to Postpone an Election? Elections during Natural Disasters, COVID-19, and Emergency Situations. Elect. Law J. Rules, Polit. Policy., 19(3), 344362. https://www.liebertpub.com/doi/pdf/10.1089/elj.2020.0642

Markowitz, A., State-by-State Guide to Face Mask Requirements. AARP, 17 November 2020. https://www.aarp.org/health/healthy-living/info-2020/states-mask-mandates-coronavirus.html

MEC (Malaysian Election Commission). Garis Panduan Pencegahan Covid-19 Bagi Pelaksanaan Pilihan Raya. 20 September, 2020.

https://www.spr.gov.my/sites/default/files/GP\%20PENCEGAHAN\%20COVID-

19\%20PELAKSANAAN\%20PILIHAN\%20RAYA_kemaskini\%20pada\%2011\%20September \%202020.pdf

MHM (Ministry of Health Malaysia), Kluster Baharu: KLUSTER BENTENG LD. 2020, 28 August, 2020. http://covid-19.moh.gov.my/sorotan/092020/kluster-baharu--kluster-benteng-ld

MHM (Ministry of Health Malaysia). Updates on the Coronavirus Disease 2019 (COVID-19) Situation in Malaysia, 04 June, 2020. https://kpkesihatan.com/2020/06/04/kenyataan-akhbarkpk-4-jun-2020-situasi-semasa-jangkitan-penyakit-coronavirus-2019-covid-19-di-malaysia/

MHM (Ministry of Health Malaysia). Updates on the Coronavirus Disease 2019 (COVID-19) Situation in Malaysia, 01 August, 2020. https://kpkesihatan.com/2020/08/01/kenyataan-akhbarkpk-1-ogos-2020-situasi-semasa-jangkitan-penyakit-coronavirus-2019-covid-19-di-malaysia/

MHNZ (Ministry of Health New Zealand), 2 New Cases of COVID-19, 25 September, 2020. https://www.health.govt.nz/news-media/media-releases/2-new-cases-covid-19-20

MHNZ (Ministry of Health New Zealand), COVID-19: Current Cases 18 November, 2020. https://www.health.govt.nz/our-work/diseases-and-conditions/covid-19-novelcoronavirus/covid-19-data-and-statistics/covid-19-current-cases

MHNZ (Ministry of Health New Zezzaland). 4 New Imported Cases of COVID-19, 16 October, 2020. https://www.health.govt.nz/news-media/media-releases/4-new-imported-cases-covid-19-0

Miller, I.F., Becker, A.D. Grenfell, B.T., Metcalf, C.J.E. (2020). Disease and Healthcare Burden of COVID-19 in the United States, Nat. Med., 26, 1212-1217. https://www.nature.com/articles/s41591-020-0952-y

Perc, M., Miksić, N.G., Slavinec, M, Stožer, A. (2020). Forecasting COVID-19. Front Phys., 8, 127(1-5). https://www.frontiersin.org/articles/10.3389/fphy.2020.00127/full

Roy. E.A., New Zealand's Three-Week Streak without Local COVID Case Ends as Port Worker Falls Ill, The Guardian, 18 October, 2020. https://www.theguardian.com/world/2020/oct/18/newzealands-three-week-streak-without-local-covid-case-ends-as-port-worker-falls-ill

Stats, New Zealand Population, 30 September 2020. https://www.stats.govt.nz/topics/population

TST (The Straits Times). Malaysia's PM Muhyiddin admits Sabah state polls in Sept caused current Covid-19 wave, 18 November 2020. https://www.straitstimes.com/asia/se-asia/malaysias-pmmuhyiddin-admits-sabah-state-polls-in-sept-caused-current-covid-19-wave 
UNGA (UN General Assembly). (1948). The Universal Declaration of Human Rights https://www.un.org/en/universal-declaration-human-rights/

UNGA (UN General Assembly). (1966). International Covenant on Civil and Political Rights https://www.ohchr.org/en/professionalinterest/pages/ccpr.aspx

USCB (United States Census Bureau), Quick facts United States-2020, 19 November, 2020. https://www.census.gov/quickfacts/fact/table/US/PST045219

USEAC (US Election Assistance Commission), Health and Safety at the Polling Place, 19 November, 2020.

https://www.eac.gov/sites/default/files/electionofficials/inpersonvoting/Health_and_Safety_at_t he_Polling_Place_052820.pdf

Waldmeir, P., Most US States Will Allow Voting Without Mask to Prevent Clashes. Financial Times, 29 October 2020. https://www.ft.com/content/654a1a54-ba18-434e-adce-e3833ef57cab 